\title{
Vocational Education Project-Based Technopreneurship Learning Model
}

\author{
Elfizon $^{1}$, MuharikaDewi $^{2}$, Ganefri $^{3}$, Sukardi $^{4}$
}

${ }^{1}$ Department of Electrical Engineering Faculty of Engineering Universitas Negeri Padang Padang, Indonesia
${ }^{2}$ English Education Study Program, Teacher Training, and Education Faculty UPI"YPTK"Padang,Indonesia

${ }^{3}$ DepartmentofElectricalEngineeringFacultyofEngineeringUniversitasNegeriPadangPadang,Indonesia

${ }^{4}$ DepartmentofElectricalEngineeringFacultyofEngineeringUniversitasNegeriPadangPadang,Indonesia

Article History: Received: 11 January 2021; Accepted: 27 February 2021; Published online: 5 April 2021

\begin{abstract}
This study aims to determine the Project-Based Technopreneurship learning model's validity value in vocational education. The model was tested using validity analysis using the Aiken $\mathrm{V}$ formula to determine internal validation criteria based on expert opinion regarding the model's quality based on the learning model elements. External validity analysis was carried out through trials with 30 research samples in applying the model; data analysis using Confirmatory Factor Analysis (CFA) aims to identify the phases' basic constructs to become a valid unified learning model. The research method was quantitative. The internal validity test sample was 7 experts in vocational education who filled out the inner validity assessment instrument. In contrast, for the external validity analysis, the example was 30 people. The instrument used was a Likert scale assessment sheet. The results showed that the V Aiken score for assessing the model's elements and the syntax phases showed an average > 0.600. In contrast, the results of the CFA analysis showed that the KMO score was 0.645> 0.500 , which means the feasibility of the data to be analyzed, the MSA score for all phases> 0.600, Total Variance Explained explains the factors formed with eigenvalues of 2,336, with the ability to explain the model as a whole $38.92 \%$.
\end{abstract}

Keywords-PBL, vocational education, technopreneurship, CFA

\section{Introduction}

The development of science and technology at this time requires humans to prepare quality human resources to keep up with every new development and field change that is happening [1][29][30][31]. Efforts that can be made to prepare quality human resources are to make changes and improvements in education [2][35]. Education and training are a priority that must continue to be carried out by the Indonesian people concerning the demands of the labor market, both at local, national, regional, and international scales. The competitiveness of the Indonesian industry at the global level is highly dependent on the quality of its human resources. The low rate of human resources will certainly have low industrial competitiveness and vice versa if human resources' quality is high. The competitiveness of the industry is also increased [3].

Quality human resources, of course, can only be produced from a quality education process. Concerning the quality of education, the Indonesian nation's education is still categorized as the highest among other countries in the world. According to UNESCO's report in "Education For All Global Monitoring Report (EVA-GMR)", Indonesia's 2014 Education For All Development Index (EDI) is ranked 57 out of 115 nations [4]. To match other countries globally, the Indonesian nation must improve itself to make breakthroughs and concrete innovations to enhance its education quality. The quality of education is closely related to the quality of the educational process itself [5]. Education is called rate in terms of the process. Suppose the learning process's implementation takes place effectively and innovatively, and students experience a meaningful learning process that is, of course, supported by adequate human resources and infrastructure. In that case, a quality learning process will undoubtedly produce quality graduates as well [6][32][33][34] [36][37][38]

One of the leading education channels to improve the nation's welfare ensures providing quality resources for work ready-to-wear is vocational education or vocational education. Vocational education graduates must have adaptive, innovative, and applicable competencies in [7] the world of work. Vocational education not only produces people who are ready to work by their scientific competencies but more than that, education is a process of how to humanize human beings who also prepared to compete according to the scientific field that is owned and ready Competition in the world market which is so competitive both in terms of trade and services aspects [8]. Vocational education has a significant role in improving human resources quality, especially in responding to challenges in improving living standards and the nation's economy. One of these challenges is the Asean Economic Community (ASEAN Economic Community), which has been in effect since early January 2016, and APEC (Asia-Pacific Economic Cooperation) in 2020.

The global market competition requires vocational education graduates who have competent skills in their hands (skills) and must have critical thinking skills who are intelligent in solving problems related to their field of expertise [9].

In response to economic globalization's needs, to motivate industry to use human capital with qualified and entrepreneurial educational graduates. Besides, there is also a need for entrepreneurial attitudes and behaviors to develop the lecture process's soft skills in tertiary institutions [10]. Entrepreneurship attitude grows in a person 
through a long process. One of the characteristics of an entrepreneurial mindset is creative and innovative thinking [11]. However, the experimental lecture process carried out so far still prioritizes the achievement of knowledge competencies in several courses in vocational training. Students are more focused on working on a series of experiments and doing tests, which causes students not to think about making the skills from assembling a series of experiments to apply them in the field. To create and become entrepreneurs, particularly technological entrepreneurs or so-called technology entrepreneurs, training must be provided to acquire practical skills and skills [12].

The learning model that education experts often recommend for implementing vocational education is project-based [13]. In technology and vocational education, this model effectively improves student practical learning outcomes [14]. Several inventions and improvements in implementing project-based learning frameworks have been carried out. So far, the main goal of developing student abilities to become technologybased entrepreneurs with the main character that refers to job readiness as professionals in electronic engineering has not been discovered.

The findings that have been made on a project-based learning model that is close to the research and development objectives carried out are carried out under the name of the e-commerce project-based learning model [15], But then for use, a more concise and valid Syntax was developed, relating to the growth of modern literacy abilities during the 4.0 epoch of the Industrial Revolution in Education. Therefore, this research is intended to clarify the feasibility of implementing a learning paradigm focused on a technical education project for technological development. Validity is an attribute that ensures that an outcome is used in the execution of the desired results [16]. This study is designed to determine whether the phases developed in the technopreneurship project-based learning model have accuracy in forming a model synthesis using CFA analysis. Previously, validity analysis was also conducted to determine the model's accuracy based on expert opinion [17].

\section{Materials \&method}

\section{A. Research Design}

This research has been carried out using quantitative research techniques, which are the basis of statistical evidence for data study [18]. This study has been carried out to assess the relevance of vocational training's technological growth paradigm, both internally and externally. The analysis method with the following design was performed:

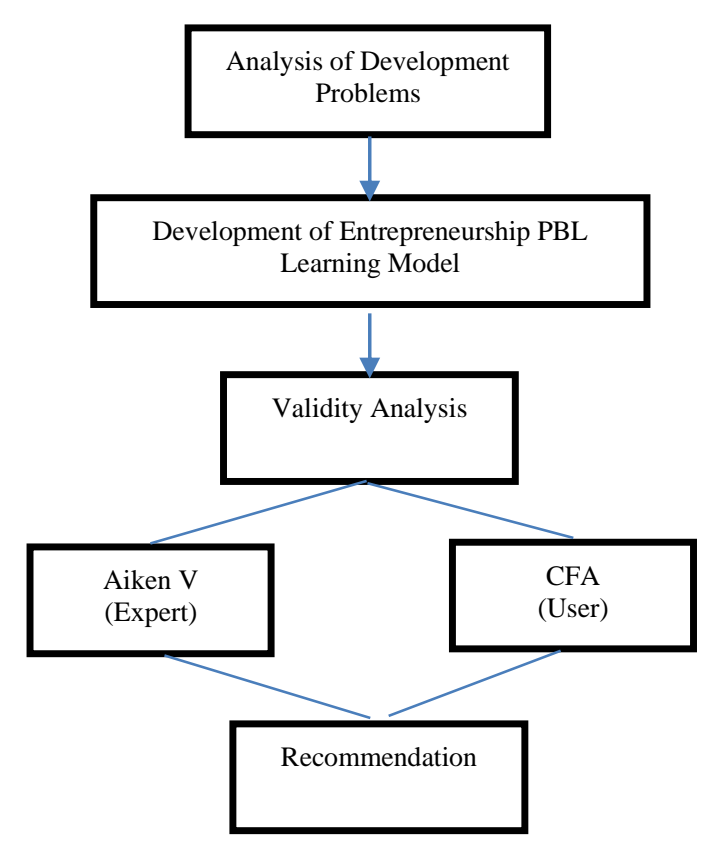

Figure 1. Research Design 


\section{B. Research Subject}

This analysis covers two testing areas: the validity of research experts to assess the model's accuracy based on model elements made by 7 experts in vocational training; the compilation of validity evidence is made after the product established has been corrected during the community discussion forum according to the revision. In the meantime, 30 students from the Faculty of Engineering of Padang State University, which evaluated the standard of phases in the technology-based learning model, were subjects for confirmatory factor analysis (CFA).

\section{Learning Model Quality Assessment Criteria}

Expert consistency assaying of learning models leads to theoretical research on the viability of a learning model using rationalization, intellectual support, grammar, social processes, response concepts, support systems, and learning effects. Further testing, namely interviewing, preparation, development, monitoring, commissioning, and assessment, will be used for syntax analysis in six stages.

\section{Data Analysis}

Data analysis measures the feasibility of the model based on expert opinion using the Aiken Validity formula proposed by Aiken (1980), with the following procedure:

$$
\mathrm{V}=\Sigma \mathrm{S} /[\mathrm{n}(\mathrm{c}-1)]
$$

$\mathrm{V}$ is the validity index of the object, $\mathrm{S}$ shall be the rater's score less the lowest score of the category ( $\mathrm{s}=\mathrm{r}-$ lo, where $\mathrm{r}=$ the form's selection score and the lowest score of the ranking category). From the perspective above, where $\mathrm{V}$ is the object's validity index, $\mathrm{s}$ is the rating given less the lower rating in the classification used. ( $\mathrm{s}=\mathrm{r}-\mathrm{lo}$, with a rater collection score and lo, the lowest score in the score range); raters count $\mathrm{n}$, and raters will estimate to c. V is the rater's index of articles' appropriateness based on the opinion mentioned earlier, with the acts to be determined using the articles. A rater indicates that $\mathrm{n}$ can be replaced by $\mathrm{m}$ if added to the meter $\mathrm{n}$ (the number of items in a tool). The value of the $\mathrm{V}$ index ranges from 0 to 1 . The nearest an object to 1 is, the higher the calculation is. When the validity score is $>0,600$, a standard score-dependent validity measuring is calculated to be accurate.

Assessment for Confirmatory Factor Analysis (CFA) is a factor analysis technique in which a priori based on previously known theories and concepts will form several factors. The formation of elements is confirmed intentionally based on ideas and concepts. Confirmatory factor analysis conducted in this study was to test whether the Syntaks developed had high-value phases as a form of the overall syntax construct. The research is carried out through the analysis process of Emperor Mayer Olkin (KMO), and Barlett's Test, Anti Image Matrices Correlation Test, Process Factoring through the method used is Principal Component Analysis with Communalities and Loading Factor and Factor Structuring stages, then performs Total Variance Explained.

\section{CONCLUSION}

\section{E. Validity Analysis Based on Expert Assessment (Expert)}

After conducting a Discussion Group Forum on developing a technopenurship project-based learning model (PBL) involving 7 experts in technology and vocational education, the researcher then revised the input and suggestions related to the learning model developed. The Project-Based Technopreneurship learning model is an alternative system. Still, it can be considered a necessity for every university to consider its application according to their respective situations and conditions. In the long term, implementing this technopreneurship-oriented education system will genuinely lead to mastery of science and technology both by universities and by the world of work/industry and the business world. This can be possible given the applied science and technology that has been cultivated, pursued, and developed consistently to the point that it can be said to be proven in Higher Education and used in the business world by the graduates of the respective tertiary institutions. Revision reference to the learning model is directed to the learning model elements, according to Joyce et al [19]. Using the appraisal method developed by the model, the expert may perform a validity assessment. The validity findings of the model are:

Table 1. Validity Results based on Expert Ratings on Model Elements

\begin{tabular}{lcc}
\hline Model Elements & $\begin{array}{c}\text { Score V } \\
\text { Aiken }\end{array}$ & Category \\
\hline Rational & 0.900 & Valid \\
Supporting & 0.881 & Valid \\
Theory & & \\
Syntax & 0.893 & Valid \\
Social System & 0.875 & Valid \\
Principle of & 0.929 & Valid \\
Reaction & & \\
\hline
\end{tabular}




\begin{tabular}{lll}
\hline Support System & 0.879 & Valid \\
Impact Model & 0.902 & Valid \\
\hline
\end{tabular}

Learning model Project-Based Technopreneurship is developed even though it is based on a rational background or reasons based on education problems. Vocational education is currently experiencing the issue of low absorption of vocational college graduates who can work by their field of expertise, placement of graduates that are not by the expected competencies [20], problems in the educational process that have not yet referred to the need to prepare graduates to be able to become entrepreneurs based on technology [21] and graduates who do not, however, have an entrepreneurial mindset [22]. These problems then become a consideration in developing a learning model oriented to becoming an entrepreneur in the 21 st century concerning expert opinion. Furthermore, the results of the validity analysis based on expert judgment on the model syntax consisting of learning steps can be seen in Table 2 below:

Table 2. Validity Results based on Expert Assessment in Model Syntax

\begin{tabular}{lcc}
\multicolumn{1}{c}{ Phase } & $\begin{array}{c}\text { Score V } \\
\text { Aiken }\end{array}$ & Category \\
\hline Phase 1. Questioning & 0.914 & Valid \\
Phase 2. Planning & 0.864 & Valid \\
Phase 3. Creating & 0.843 & Valid \\
Phase 4. Controlling & 0.879 & Valid \\
Phase 5. & 0.893 & Valid \\
Commissioning & & \\
Phase 6. Evaluating & 0.900 & Valid \\
\hline
\end{tabular}

Based on the validity score calculation results based on the expert's evaluation of the stages that have been developed, it can be clarified that the developed learning model was considered valid at each step since $>0.600$ was obtained from the V Aiken score. It can be seen that this technopreneurship is a project-based learning model that has an element of the primary model, namely a syntax, which is the stage of implementing this model. The phases of the project-based learning model proposed in this model are developed based on several existing models explicitly designed for application to vocational education, reference to several models developed from the learning model from the Ministry of Education and Culture, The Seven Steps of PjBl Model [23 ], An ECommerce Project-based Learning Model [15]. Some of the innovations in the development of the model carried out are the phases that help students develop creative and innovative thinking skills to students in identifying ideas and analyzing ideas by supporting the study of problem-solving concepts in their science so that they can solve technological difficulties, forecast operational costs and prospective people in business through a project [24] [25].

\section{F. Validity Analysis based on User Ratings}

Then to find out how to analyze the validity of the phases in the model syntax based on the model user assessment, data analysis was carried out by capturing the evaluation of model users. That is to say, students of the research program in electronic engineering, Faculty of Engineering, Padang State University. The validity analysis results using Confirmatory Factor Analysis (CFA) to confirm the phases in forming a new model. The results of the analysis are described as follows:

\section{- KMO and Bartlett Test Sphericity}

Testing the accuracy of the formed factors used Barlett's Test of Sphericity statistical test with a significant value of $<0.05$ and Kaiser Mayer Olkin (KMO) to determine factor analysis feasibility.

Table 3. KMO and Bartlett Test Sphericity

\begin{tabular}{|c|c|c|}
\hline \multicolumn{3}{|c|}{ KMO and Bartlett's Test } \\
\hline \multicolumn{2}{|c|}{ Kaiser-Meyer-Olkin Measure of Sampling Adequacy } & .645 \\
\hline \multirow[t]{3}{*}{ Barlett Test Sphericity } & Approx. Chi-Square & 25.893 \\
\hline & df. & 15 \\
\hline & Sig. & .041 \\
\hline
\end{tabular}

Based on the results in Table 3, it is known that the Kaiser-Mayer Olkin Sampling Adequacy Measure score indicates a score of 0.645 with a significance of 0.041 since the KMO value is already above $0.600(0.645>$ 0.600 ), and the significance is much higher than 0.050 , and the data can be further analyzed.

\section{- Anti-Image Matrices and Communalities}

The results of the Anti-Image Matrices and Communalities test can be seen in the anti-image matrices table by taking into account the value of the Measure of Sampling Adequacy (MSA) as follows: 
Table 4. Anti-Image Matrices

\begin{tabular}{|l|c|}
\hline \multicolumn{1}{|c|}{ Factor } & MSA figures \\
\hline Phase 1. Questioning & 0.659 \\
\hline Phase 2. Planning & 0.653 \\
\hline Phase 3. Creating & 0.650 \\
\hline Phase 4. Controlling & 0.662 \\
\hline Phase 5. Commissioning & 0.641 \\
\hline Phase 6. Evaluating & \\
\hline
\end{tabular}

The MSA score is at a score of $>0.600$, which means that all phases correlate, and no phase must be discarded to form a complete model syntax. Furthermore, to find out the role of each stage in developing a full syntax, it can be seen in the Communalities table below:

Table 5. Communalities

\begin{tabular}{|l|c|c|c|}
\hline \multicolumn{1}{|c|}{ Factor } & Initial & Extraction & $\begin{array}{c}\text { Phase } \\
\text { Contribution }\end{array}$ \\
\hline $\begin{array}{l}\text { Phase 1. } \\
\text { Questioning }\end{array}$ & 1 & 0.404 & $40.4 \%$ \\
\hline Phase 2. Planning & 1 & 0.470 & $47.0 \%$ \\
\hline Phase 3. Creating & 1 & 0.435 & $43.5 \%$ \\
\hline $\begin{array}{l}\text { Phase 4. } \\
\text { Controlling }\end{array}$ & 1 & 0.335 & $33.5 \%$ \\
\hline $\begin{array}{l}\text { Phase } \\
\text { Commissioning }\end{array}$ & 1 & 0.300 & $30.0 \%$ \\
\hline $\begin{array}{l}\text { Phase } \\
\text { Evaluating }\end{array}$ & & 0.392 & $39.2 \%$ \\
\hline
\end{tabular}

\section{- Total Variance Explained}

To find out the number of syntax components that are formed from all factors (phases), it can be seen based on the element builds in the total variance explained table. It can be seen that the factor created is only 1 factor based on the calculation since only 1 component has the number of Eigenvalues $>1$. The above table shows that the elements produced with 2.336 eigenvalues are 38.92 percent, with the potential to clarify the overall model. The syntax components' development based on the model phases will be defined in Table 6 and the Scree Plot Figure in Figure 2.

Table 6. Total Variance Explained

\begin{tabular}{|c|r|r|r|r|r|r|}
\hline \multirow{2}{*}{$\begin{array}{c}\text { Componen } \\
\text { t }\end{array}$} & \multicolumn{3}{|c|}{ Initial Eigenvalues } & \multicolumn{2}{|c|}{$\begin{array}{c}\text { Extraction Sums of Squared } \\
\text { Loadings }\end{array}$} \\
\cline { 2 - 7 } & Total & $\begin{array}{c}\text { \% of } \\
\text { Variance }\end{array}$ & $\begin{array}{c}\text { Cumulative } \\
\text { \% }\end{array}$ & Total & $\begin{array}{c}\text { \% of } \\
\text { Variance }\end{array}$ & $\begin{array}{c}\text { Cumula } \\
\text { tive \% }\end{array}$ \\
\hline 1 & 2.336 & 38.927 & 38.927 & 2.336 & 38.927 & 38.927 \\
2 & .987 & 16.452 & 55.379 & & & \\
3 & .907 & 15.125 & 70.504 & & & \\
4 & .851 & 14.187 & 84.691 & & & \\
5 & .484 & 8.063 & 92.753 & & & \\
6 & .435 & 7.247 & 100.000 & & & \\
\hline
\end{tabular}


Table 6. Total Variance Explained

\begin{tabular}{|c|c|c|c|c|c|c|}
\hline \multirow[b]{2}{*}{$\begin{array}{c}\text { Componen } \\
\mathbf{t}\end{array}$} & \multicolumn{3}{|c|}{ Initial Eigenvalues } & \multicolumn{3}{|c|}{$\begin{array}{l}\text { Extraction Sums of Squared } \\
\text { Loadings }\end{array}$} \\
\hline & Total & $\begin{array}{c}\% \text { of } \\
\text { Variance }\end{array}$ & $\underset{\%}{\text { Cumulative }}$ & Total & $\begin{array}{c}\% \text { of } \\
\text { Variance }\end{array}$ & $\begin{array}{l}\text { Cumula } \\
\text { tive } \%\end{array}$ \\
\hline 1 & 2.336 & 38.927 & 38.927 & 2.336 & 38.927 & 38.927 \\
\hline 2 & .987 & 16.452 & 55.379 & & & \\
\hline 3 & .907 & 15.125 & 70.504 & & & \\
\hline 4 & .851 & 14.187 & 84.691 & & & \\
\hline 5 & .484 & 8.063 & 92.753 & & & \\
\hline
\end{tabular}

Extraction Method: Principal Component Analysis.

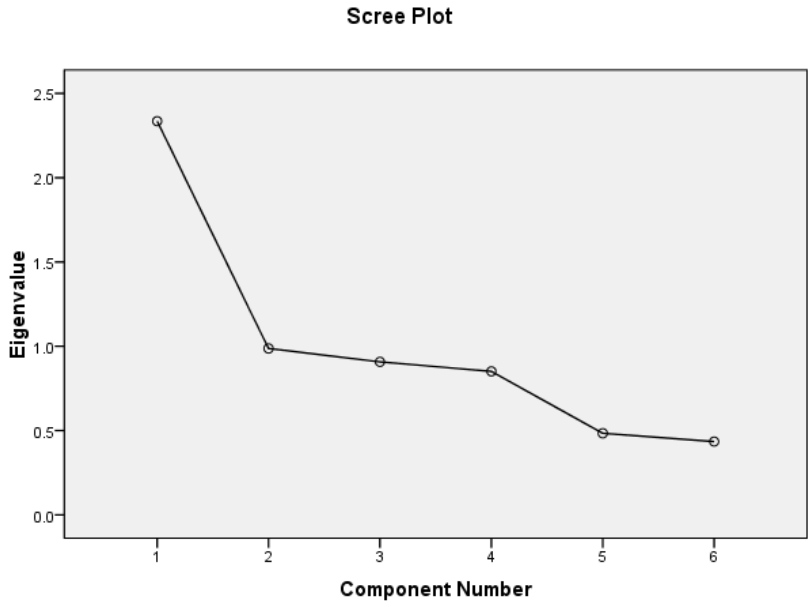

Figure 2. Scree Plot Component Formed

\section{- Loading Factor and Factor Arrangement}

To get a high factor loading on one part and a low factor loading on the other variables, Orthogonal Varimax rotation is carried out. Grouping is achieved by paying attention to the numbers of the coefficients found in the variable row column and factor. However, because there is only one factor formed, there is no factor rotation.

The CFA data analysis results that have been carried out conclude that the Project-Based Technopreneurship learning model that has been developed shows a new model with innovation invalid phases into a new syntax. Learning in vocational education should be supported by a project-based learning model [26]. It can form an ability by practicing reasoning in solving fundamental problems that should be a business opportunity for an entrepreneur. A project-based learning model that is by the learning objectives of vocational education with phases starting from the formulation of essential questions from the community's real conditions encourages links and matches, which are the vocational education principles [27] [28]. It is hoped that this learning model can be applied to practical learning in vocational education by modifying instructional goals according to the basis of technopreneurship.

\section{References}

1. M. I. Ghareb, Z. Ali Ahmed, and A. A. Ameen, "Planning Strategy and The Use of Information Technology in Higher Education: A Review Study in Kurdistan Region Government," JOIV Int. J. Informatics Vis., vol. 3, no. 3, pp. 283-287, 2019, doi: 10.30630/joiv.3.3.263.

2. M. Kadarisman, "Tantangan Perguruan Tinggi dalam Era Persaingan Global,” Sociae Polites, vol. 1, no. 1, pp. 3-20, 2011.

3. W. Djojonegoro, Pengembangan Sumber Daya Manusia melalui SMK. Jakarta: Jayakarta Agung Offset, 1998.

4. Ahmad, "Pengukuran Education for All Development Index ( Edi ) Indonesia Tahun 20112015," Semin. Nas. dan Disk. Panel Multidisiplin Has. Penelit. Pengabdi. Kpd. Masy., no. 5, pp. 252- 
$261,2018$.

5. Handb. Ser., vol. 2, pp. 5-46, 2006.

6. S. S. Noesgaard and R. Ørngreen, "The effectiveness of e-learning: An explorative and integrative review of the definitions, methodologies and factors that promote e-Learning effectiveness," Electron. J. e-Learning, vol. 13, no. 4, pp. 278-290, 2015.

7. N. Asriati, "Pengembangan Model Pembelajaran Teaching Factory 6M Menghadapi Revolusi Industri Keempat Di Smk Negeri 6 Pontianak,” JURKAMI J. Pendidik. Ekon., vol. 3, no. 2, pp. 70-86, 2019, doi: 10.31932/jpe.v3i2.334.

8. N. Jalinus, "Pengembangan Pendidikan Teknologi dan Kejuruan dan Hubungan Dunia Kerja," Jurnal Pendidikan Vokasi, vol. 1, no. 1. pp. 25-34, 2011.

9. Ganefri, Indrati K, Hendra H, and Aznil M, "Need Analysis of Entrepreneurship's Pedagogy of Technology and Vocational Education in Higher Education," 2016.

10. M. Dewi, E. Susanti, R. Susanti, Z. Yenni, and E. Eliza, "The Effect Of Mindset Personal On Behavior Of Internet Entrepreneurship Students Of Universitas Putra Indonesia Yptk Padang," Sosiohumaniora, 2020, doi: 10.24198/sosiohumaniora.v22i1.25625.

11. A. Wesnita and M. Dewi, "Analysis of Quality and Output of Entrepreneurship in the Field of Refractionist Optician," IOP Conf. Ser. Mater. Sci. Eng., vol. 306, no. 1, 2018, doi: 10.1088/1757899X/306/1/012010.

12. [12] R. Shpeizer, "Towards a successful integration of project-based learning in higher education: Challenges, technologies and methods of implementation," Univers. J. Educ. Res., vol. 7, no. 8, pp. 1765-1771, 2019, doi: 10.13189/ujer.2019.070815.

13. [13] A. Hasani, A. Hendrayana, and A. Senjaya, "Using Project-based Learning in Writing an Educational Article: An Experience Report," Univers. J. Educ. Res., vol. 5, no. 6, pp. 960-964, 2017, doi: 10.13189/ujer.2017.050608.

14. Z. A. Putra and M. Dewi, "The Application of Problem-Based Learning in Mechanical Engineering," IOP Conf. Ser. Mater. Sci. Eng., vol. 306, no. 1, 2018, doi: 10.1088/1757899X/306/1/012140.

15. M. Dewi, K. Rukun, and A. Efi, "Exspert Validity Pada Pengembangan Model Pembelajaran Berbasis Proyek E Commerce Pada Pembelajaran Kewirausahaan," J. Pendidik. Teknol. Kejuru., 2018, doi: 10.24036/jptk.v1i2.923.

16. Ambiyar and M. Dewi, Metodologi penelitian evaluasi program, 1st ed. Bandung: CV. Alfabeta Bandung, 2019.

17. R. Heri, "Proving Content Validity Of Self-Regulated Learning Scale (The Comparison Of Aiken Index And Expanded Gregory Index),"Res. Eval. Educ., vol. 2, no. 2, pp. 155-164, 2016.

18. Ambiyar dan Muharika, "Metodologi Penelitian Evaluasi Program," Int. J. Physiol., 2018.

19. E. C. Bruce Joyce, Marsha Weil, Models of Teaching (Eight Edition*), 5th ed. P, 2011.

20. Gozali, N. Amaliah, and E. Milaningrum, "Revitalisasi Poltekba era industri 4.0," JVTE J. Vocat. Tech. Educ., vol. 1, no. 2, pp. 19-26, 2019.

21. Ganefri, "The development of production-based learning approach to entrepreneurial spirit for engineering students," Asian Soc. Sci., vol. 9, no. 12 SPL ISSUE, pp. 162-167, 2013, doi: 10.5539/ass.v9n12p162.

22. M. Dewi, E. Susanti, R. Susanti, Z. Yenni, and E. Eliza, "the Effect of Mindset Personal on Behavior of Internet Entrepreneurship Students of Universitas Putra Indonesia Yptk Padang," Sosiohumaniora, vol. 22, no. 1, p. 1, 2020, doi: 10.24198/sosiohumaniora.v22i1.25625.

23. N. Jalinus, R. A. Nabawi, and A. Mardin, "The Seven Steps of Project Based Learning Model to Enhance Productive Competences of Vocational Students," no. January, 2017, doi: 10.2991/ictvt17.2017.43.

24. T. Markham, Project Based Learning: Design and Coaching Guide. Canada: Wilsted \& Taylor Publishing Services, 2012.

25. R. Efendi, "Implementation of Project Based Learning: Research Overview," Appl. Sci. Technol., vol. 1, pp. 280-285, 2017.

26. A. Yulastri, H. Hidayat, Ganefri, S. Islami, and F. Edya, "Developing an Entrepreneurship Module by Using Product-Based Learning Approach in Vocational Education," Int. J. Environ. Sci. Educ., vol. 12, no. 5, pp. 1097-1109, 2017.

27. M. Dewi, Y. Retno Sari, S. Amna, Rasmita, and R. Susanti, "The understanding of lecturers about the new literacy in industrial revolution era 4.0: A study case of university of Putra Indonesia yptk Padang," J. Phys. Conf. Ser., vol. 1339, no. 1, pp. 0-7, 2019, doi: 10.1088/17426596/1339/1/012105.

28. A. Yulastri, H. Hidayat, G. Ganefri, F. Edya, and S. Islami, "Learning outcomes with the application of product based entrepreneurship module in vocational higher education," J. Pendidik. Vokasi, vol. 8, no. 2, p. 120, 2018, doi: 10.21831/jpv.v8i2.15310.

29. Yang, C., Novaliendry, D., Chen, J., Wattimena, F. Y., Renyaan, A. S., Lizar, Y., ... Nasution, T. (2020). Prediction of Mortalityinthe Hemodialysis Patient with Diabetes using Support Vector Machine. 
Revista Argentina de Clínica Psicológica, XXIX, 219-232. https://doi.org/10.24205/03276716.2020.823

30. Novaliendry, D., Wattimena, F. Y., Renyaan, A. S., Lubis, A. S., Ramadhani, D., Lizar, Y., Guci, A., Rais, S., Sriwahyuni, T., Al Kutsi, M. I., Yang, C. H., Verawardina, U., Nasution, T., Khairul. (2020). Development of an Expert System Application to Detect Vitamin Deficiencies in the Human Body. Revista Argentina de Clínica Psicológica, XXIX, 956-965. https://doi.org/10.24205/03276716.2020.1092

31. D. Novaliendry,Y.Hendriyani, C-H.Yang, \& H. Hamimi, 2015, The Optimized K-Means Clustering Algorithms to Analyezed the Budget Revenue Expenditure in Padang. Proceeding of International Conference on Electrical Engineering, Computer Science and Informatics, 61-64

32. Krismadinata, Unung Verawardina, Nizwardi Jalinus, Fahmi Rizal, Sukardi, Putu Sudira, Dochi Ramadhani, Arina Luthfini Lubis, John Friadi, Ari Syaiful Rahman Arifin, Dony Novaliendry. Blended Learning as Instructional Model in Vocational Education: Literature Review. Universal Journal of Educational Research, vol. 8, 11b, pp. 5801 - 5815, 2020. DOI: 10.13189/ujer.2020.082214

33. Novaliendry, D., Darmi, R., Hendriyani, Y., Nor, M., \& Azman, A. (2020). Smart Learning Media Based on Android Technology. International Journal of Innovation, Creativity and Change., 12(11), 715-735.

34. [34] Dony Novaliendry, Muhammad Adri, Putra Jaya, Titi Sriwahyuni, Asrul Huda, Yasdinul Huda, Dedy Irfan, Dochi Ramadhani, Sartika Anori, "Development of Smart Learning Media Model Based on Android", International Journal of Engineering Research and Technology. ISSN 0974-3154, Volume 14, Number 1 (2021), pp. 168-178

35. [35] Dony Novaliendry, Arif Subagia, Titi Sriwahyuni, Fegie Y Wattimena, Axelon S Renyaan, Ceng-Hong Yang, Putra Jaya. 2021. Designing Augmented Reality-Based Computer Devices Learning Media on Android Platform. 4th Forum in Research Science, and Technology (FIRST-T1-T2-2020). Atlantis Highlights in Engineering.

36. Husein, Ismail H Mawengkang, S Suwilo "Modeling the Transmission of Infectious Disease in a Dynamic Network" Journal of Physics: Conference Series 1255 (1), 012052, 2019.

37. Husein, Ismail, Herman Mawengkang, Saib Suwilo, and Mardiningsih. "Modelling Infectious Disease in Dynamic Networks Considering Vaccine." Systematic Reviews in Pharmacy 11.2, pp. 261-266, 2020.

38. Husein, Ismail, Dwi Noerjoedianto, Muhammad Sakti, Abeer Hamoodi Jabbar. "Modeling of Epidemic Transmission and Predicting the Spread of Infectious Disease." Systematic Reviews in Pharmacy 11.6 (2020), 188-195. Print. doi:10.31838/srp.2020.6.30

39. Husein, Ismail, YD Prasetyo, S Suwilo "Upper generalized exponents of two-colored primitive extremal ministrong digraphs"AIP Conference Proceedings 1635 (1), 430-439, 2014

40. Husein Ismail, Rahmad Syah, "Model of Increasing Experiences Mathematics Learning with Group Method Project", International Journal of Advanced Science and Technology, pp. 1133-1138, 2020.

41. Verawadina, U., Jalinus, N., Krismadinata, Widya, R.N., \& Simeru, A. 2020. Needs Assessment of ELearning Vocational Education. International Journal of Innovation, Creativity and Change, 11(4), 262-274.

42. Vitriani, Ali, G., Nanda, D. W., Syahril, Desnelita, Y., Satria, R., \& Verawadina, U. 2020. The validity of training models based on knowledge management systems. International Journal of Innovation, Creativity, and Change,12(12), 726-741.

43. Nofrianto, H., Jama, J., \& Indra, A. (2020). Validity of Cooperative-Discovery Learning Model to Improve Competencies of Engineering Students. Systematic Reviews in Pharmacy, 11(12), 1134-1138. 